\title{
MYCOBIOTA ASSOCIATED WITH HYLURGOPS PALLIATUS (GYLL.) ON PINUS SYLVESTRIS L. IN POLAND
}

\author{
ROBERT JANKOWIAK \\ Department of Forest Pathology \\ Agriculture University \\ Al. 29 Listopada 46, 31-425 Kraków, Poland \\ e-mail: rljankow@cyf-kr.edu.pl
}

(Received: March 3, 2006. Accepted: June 7, 2006)

\begin{abstract}
The assemblage and abundance of fungal species associated with Hylurgops palliatus on Pinus sylvestris, were studied in Poland. Fungi were isolated from beetles of $H$. palliatus and their galleries collected from three populations. In total, 1832 fungal isolates, including 38 species, were obtained. The most important group of fungi were the ophiostomatoid fungi. Among the seven species of ophiostomatoid fungi isolated, Leptographium lundbergii and an unknown species of Graphium sp. code-named 'W' were the dominant species. Ophiostoma minus and $O$. piceae were also relatively common. All ophiostomatoid species, except L. lundbergii occurred more frequently on the overwintered adults than in gallery systems. Ophiostoma minus and $O$. piliferum are documented here as new associates of $H$. palliatus.
\end{abstract}

KEY WORDS: Hylurgops palliatus, Leptographium lundbergii, Ophiostomatoid fungi, Pinus sylvestris.

\section{INTRODUCTION}

Many species of fungi are known to be associated with bark beetles (Kirisits 2004; Upadhyay 1981). Among them, blue-stain fungi, especially ophiostomatoid species, are most frequently associated with bark beetles infesting coniferous trees (Wingfield et. al. 1993). These fungi are an important fungal group because they cause blue-staining in freshly cut logs and some of them are capable of killing mature trees (Harrington 1993).

Many species of bark beetles, for example Ips typographus (L.), are considered the major forest pests. Hylurgops palliatus (Gyll.) is not considered to be an economically important pest in its natural range because it infests logs, stumps and dead or dying trees. However, when the population level of $H$. palliatus is high it may also attack live trees. In Europe, H. palliatus breeds in conifers of the family Pinaceae including species of Abies spp., Larix spp., Picea spp. and Pinus spp. Hylurgops palliatus may have one or two generations per year in Poland. In April-May and July-August adults establish galleries in the phloem (Michalski and Mazur 1999). During gallery construction, the beetles disseminate the spores of the blue-stain fungi. Propagules of blue-stain fungi are carried on the external surface of the exoskeletons of $H$. palliatus and in very primitive mycangia. Among the ophiostomatoid fungi transmitted by $H$. palliatus, there are pathogenic fungi which may play a role in overcoming the resistance of trees attacked by the beetles (Kiristis 2004).

Several reports on the fungi associated with $H$. palliatus have been published in Europe (Harding 1989; Jacobs and Wingfield 2001; Jacobs et. al. 2001; Kirisits et. al. 2000; Kirisits 2001; Kirschner 1998, 2001; Kotýnková-Sychrová 1966; Krokene and Solheim 1996; Mathiesen 1950; Mathiesen-Käärik 1953; Wingfield and Gibbs 1991). These studies were focussed on the species of blue-stain fungi associated with $H$. palliatus on Norway spruce. Ambrosiella sp., Leptographium lundbergii Lagerb. \& Melin, Ophiostoma ainoae $\mathrm{H}$. Solheim, O. cucullatum H. Solheim, O. neglectum Kirschner et Oberwinkler, O. penicillatum (Grosm.) Siem., O. piceae (Münch) Syd. \& P. Syd. and $O$. piceaperdum (Rumb.) von Arx were a dominant fungal species.

There was no report about mycobiota associated with $H$. palliatus in Poland. Some of the blue-stain fungi were isolated from other pine bark beetles by Siemaszko (1939). He reported, that in the Białowieża Forest, Ophiostoma ips (Rumbold) Nannf., O. minus (Hedgc.) Syd. \& P. Syd. and $O$. minus were associated with I. sexdentatus (Börn.) and Tomicus piniperda (L.), respectively.

In this study, composition and frequency of fungi associated with $H$. palliatus on Scots pine were investigated. This was achieved by isolating fungi from the beetle bodies and their galleries. 


\section{MATERIALS AND METHODS}

\section{Study site}

The investigations were conducted in 2005 in three study plots located in Pinus sylvestris stands in the Niepołomice Forest District (49 59'53' ' N, 20¹9'56', E), Oleszyce Forest District $\left(50^{\circ} 07^{\prime} 45^{\prime}\right.$ ' $\mathrm{N}, 22^{\circ} 57^{\prime} 17^{\prime}$ ' E) and Olkusz Forest District $\left(50^{\circ} 14^{\prime} 28^{\prime}, \mathrm{N}, 19^{\circ} 31^{\prime} 25^{\prime}, \mathrm{E}\right)$. All plots were located in 40-50 years old pine stands, where $P$. sylvestris was the dominant species. Fungal isolations were made from the beetles colonizing trees and tissues of trees colonized by the first generation of $H$. palliatus.

\section{Fungal isolation from the beetles}

The main attack of $H$. palliatus started on 2 April. On 27 and 28 April, four trees attacked by $H$. palliatus at each location were felled and adults were collected from its galleries. The bark of felled trees was peeled with a sterilized hatchet. The galleries of $H$. palliatus were not well developed and overwintered adult beetles, eggs and young larvae were found. The beetles were collected with sterilized tweezers and then stored individually in sterile microtubes $(1.5$ $\mathrm{ml}$ ) for isolations. In total, 192 adults were picked up from galleries.

Before isolation of fungi, each beetle was bathed in sterile water for 30 seconds. After drying on a sterile blotting paper, the beetles were crushed on a microscopic slide and evenly spread on the surface of medium, with a sterile scalpel.

\section{Fungal isolation from the gallery systems}

Samples were taken from gallery systems found on the trees felled on 27 and 28 April. From parts of the stem infested by $H$. palliatus four sections $(30 \mathrm{~cm}$ long) were cut from each tree and transported to the laboratory. The sections were cut from the tree stems between 2 and $4 \mathrm{~m}$ above the ground. In the laboratory, the bark was separated from the wood under sterile conditions. Fragments of the gallery from which isolations were intended were disinfected using cotton wool with $96 \%$ ethyl alcohol. The disinfection lasted approximately $15 \mathrm{sec}$. and then gallery fragments were dried on filter paper. Isolation of fungi was made from phloem fragments taken from egg and larval galleries of $H$. palliatus and around them. Isolations of fungi were also made from the stained or discoloured sapwood underneath insect galleries up to a depth of $20 \mathrm{~mm}$ into the sapwood. After drying of samples, the surface layer of phloem tissues was removed with a sterile scalpel. Subsequently, small fragments of phloem or sapwood (about $4 \times 4$ $\mathrm{mm}$ ) were cut with a sterile scalpel or a chisel, and placed on a culture medium in Petri dishes. In total, 828 plant pieces were used in this study.

\section{Cultural procedures}

All of the isolations were made on $2 \%$ malt extract agar (2\% MEA; $20 \mathrm{~g}$ malt extract, $20 \mathrm{~g}$ agar, $1000 \mathrm{ml}$ distilled water) supplemented with the antibiotic tetracycline (200 mg per 1 litre of culture medium) to inhibit bacterial growth. Where necessary, cultures were purified by transferring small pieces of mycelium or spore masses from individual colonies to fresh $2 \%$ MEA. The primary isolation plates were incubated at room temperature in the darkness. Emerging fungi were identified on the morphological cha- racters such as perithecia, ascospores, conidiophores and conidia.

\section{Frequency of occurrence}

Frequencies were computed using the following formula: $F=(N F / N T) \times 100$, where $F$ represents the frequency of occurrence $(\%)$ of each fungal species, $N F$ represents number of beetles or plant fragments, from which a particular fungus was isolated and NT represents total number of beetles or plant fragments from which fungal isolation was attempted. Fungal frequencies were computed together for phloem and sapwood fragments.

\section{RESULTS}

In this study, 1832 fungal isolates were obtained from adult beetles and gallery systems. In total, 31 fungal species were isolated from the beetles and 20 from the gallery systems. These fungi represented mainly ascomycetes and anamorphic fungi, but a few zygomycetes were also isolated. The most important group of fungi were ophiostomatoid fungi, represented by seven species: Ophiostoma minus, O. piceae, O. piliferum (Fr.) Syd. \& P. Syd., Ceratocystiopsis alba (DeVay, R.W. Davidson \& W.J. Moller) H.P. Upadhyay, Leptographium lundbergii, Graphium sp. 'W' and Graphium sp. 'D'(Tables 1,2).

\section{Fungal isolations from beetles}

Approximately $96 \%$ of the 192 beetles carried fungi (Table 1). Among the species isolated from the beetles, five ophiostomatoid fungi were identified: $O$. minus, $O$. piceae, L. lundbergii, Graphium sp. 'W' and Graphium sp. 'D'. All ophiostomatoid species, except Graphium sp. 'D' were isolated from beetles in all populations. Leptographium lundbergii was the most commonly isolated fungus (isolated from 34.4 to $73.4 \%$ of beetles). Graphium sp. 'W' was the second most abundant fungus (31.3-35.9\%). Two other ophiostomatoid fungi, O. minus and $O$. piceae were isolated from 12.5 to $29.7 \%$ and $15.6-23.4 \%$ of beetles, respectively (Table 1). Among other species, Trichoderma spp., Penicillium spp., Mucor sp. and Mortierella ramanniana var. ramanniana (A. Möller) Linnem. were most abundant (Table 1).

\section{Fungal isolations from gallery systems}

Overall, $97.6 \%$ of the 828 plant fragments taken from colonized trees contained fungi (Table 2). Seven species of ophiostomatoiod fungi, C. alba, O. minus, O. piceae, O. piliferum, L. lundbergii, Graphium sp. 'W' and Graphium sp. 'D' were isolated from gallery system. All species, except C. alba, O. piliferum and Graphium sp. 'D' were isolated from $H$. palliatus gallery systems in all populations. Leptographium lundbergii was isolated most frequently and was found in $81.8 \%$ of all samples. Graphium sp. 'W' was isolated from $33.7 \%$ of plants fragments. The remaining ophiostomatoid species were isolated less frequently. Ophiostoma minus and $O$. piceae were isolated from 15.2 and $6.6 \%$ of all samples, respectively. Species not belonging to the ophiostomatoid fungi were relatively rare. Among these fungi, one ascomycetes Dipodascus aggregatus FranckeGrosm. as well as anamorphic fungi (Trichoderma spp., $P e$ nicillium spp.) were most abundant (Table 2). 
TABLE 1. Frequency of occurrence (\%) of fungi isolated from beetles of Hylurgops palliatus collected at three locations.

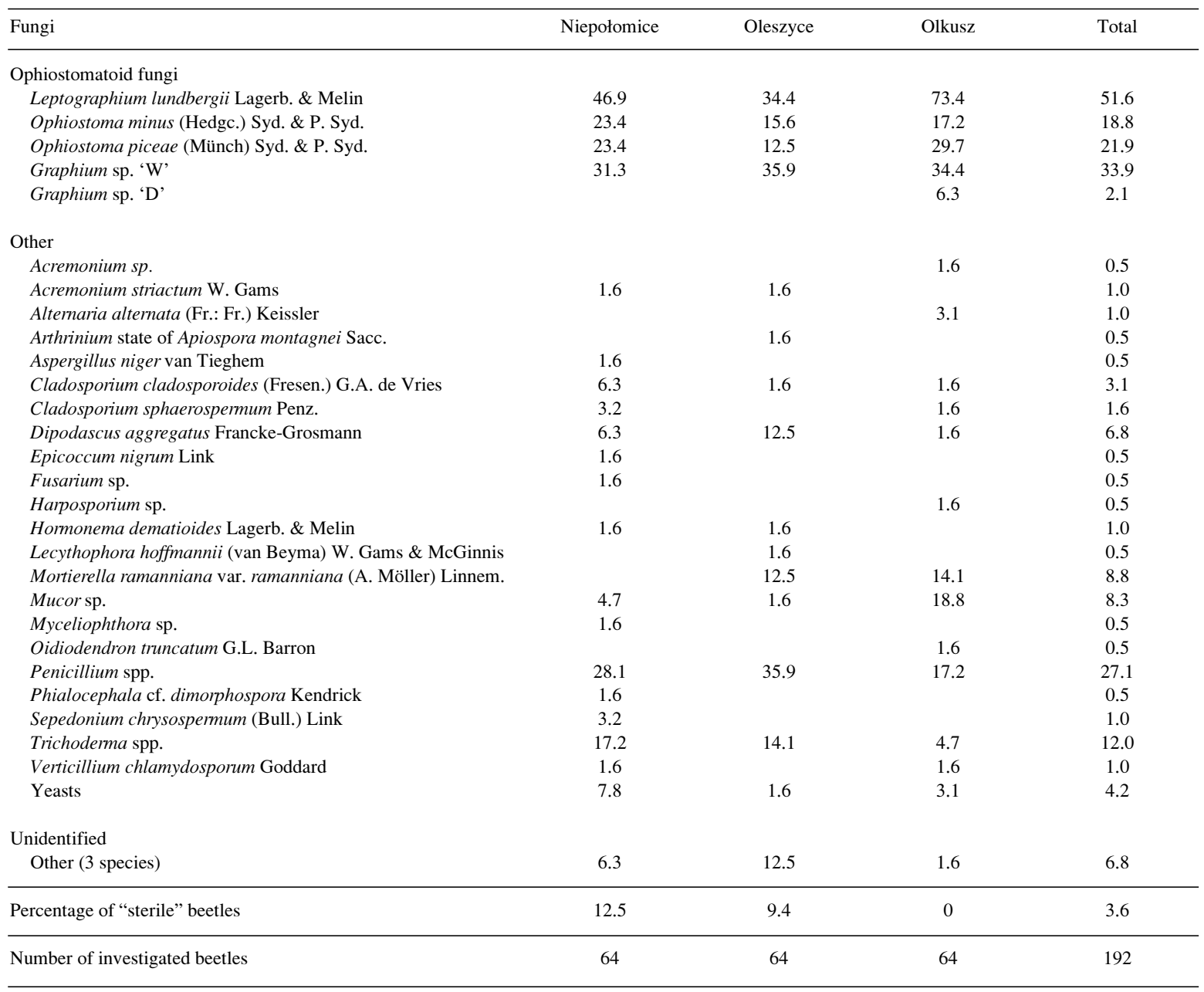

\section{DISCUSSION}

In this study, the ophiostomatoid fungi were the most common fungal associates of the $H$. palliatus and they were represented by seven species. These fungi were isolated from the beetles as well as from gallery systems. Among them, L. lundbergii and Graphium sp. 'W' had high frequency of occurrence, suggesting a close association with $H$. palliatus. Kotýnková-Sychrová (1966) described only $L$. lundbergii as fungal associate of $H$. palliatus on Picea abies and $P$. sylvestris trees in formerly Czechoslovakia. In contrast to Kotýnková-Sychrová's investigations, Wingfield and Gibbs (1991) reported a wide variety of Leptographium and Graphium species to be associated with $\mathrm{H}$. palliatus in England. These authors found that Leptographium procerum (W.B. Kendr.) M.J. Wingf., L. truncatum (M.J. Wingf. \& Marasas) M.J. Wingf., L. wingfieldii M. Morelet, L. guttulatum M.J. Wingf., K. Jacobs and the two undescriebd species Graphium sp. were associated with new adults of $H$. palliatus trapped in $P$. sylvestris billets. Hylurgops palliatus is also associated with a number of blue-stain fungi on Norway spruce (Jacobs and Wingfield 2001; Jacobs et. al. 2001; Harding 1989; Kirisits at al. 2000; Kirisits 2001; Kirschner 1998, 2001; Krokene and Solheim 1996; Mathiesen 1950; Mathiesen-Käärik 1953). Among them, L. lundbergii, O. ainoae, O. cucullatum, O. neglectum, $O$. penicillatum, $O$. piceae and $O$. piceaperdum were dominant fungal species. These ophiostomatoid fungi are known to be commonly associated with bark beetle species infesting Norway spruce in Europe (Harding 1989; Jankowiak 2005; Kirisits 2001; Kirschner 1998; Sallè et. al. 2005; Solheim 1986; Viiri 1997; Viiri and Lieutier 2004). Among them, only $L$. lundbergii and $O$. piceae were also found to be associated with $H$. palliatus on $P$. sylvestris in this study. It may suggest that $L$. lundbergii and $O$. piceae are the most consistent but unspecific associates of $\mathrm{H}$. palliatus. However, the populations of insects occurring in $P$. sylvestris forests may carry additionally $O$. minus, $O$. piliferum and Graphium sp. 'W' but other H. palliatus populations breeding in $P$. abies trees transmitted also ophiostomatoid fungi associated with other bark beetle species on spruce.

In this study, L. lundbergii was the most commonly isolated species from overwintered adults constructing new galleries. It suggests that propagules of this fungus are especially frequently introduced to Scots pine by beetles of H. palliatus in Poland. Kotýnková-Sychrová (1966) considered that $L$. lundbergii may be frequently isolated shortly after the initiation of the brood systems. In this phase of brood development it caused yellow-brown discoloration 
TABLE 2. Frequency of occurrence (\%) of fungi isolated from gallery systems of Hylurgops palliatus collected at three locations.

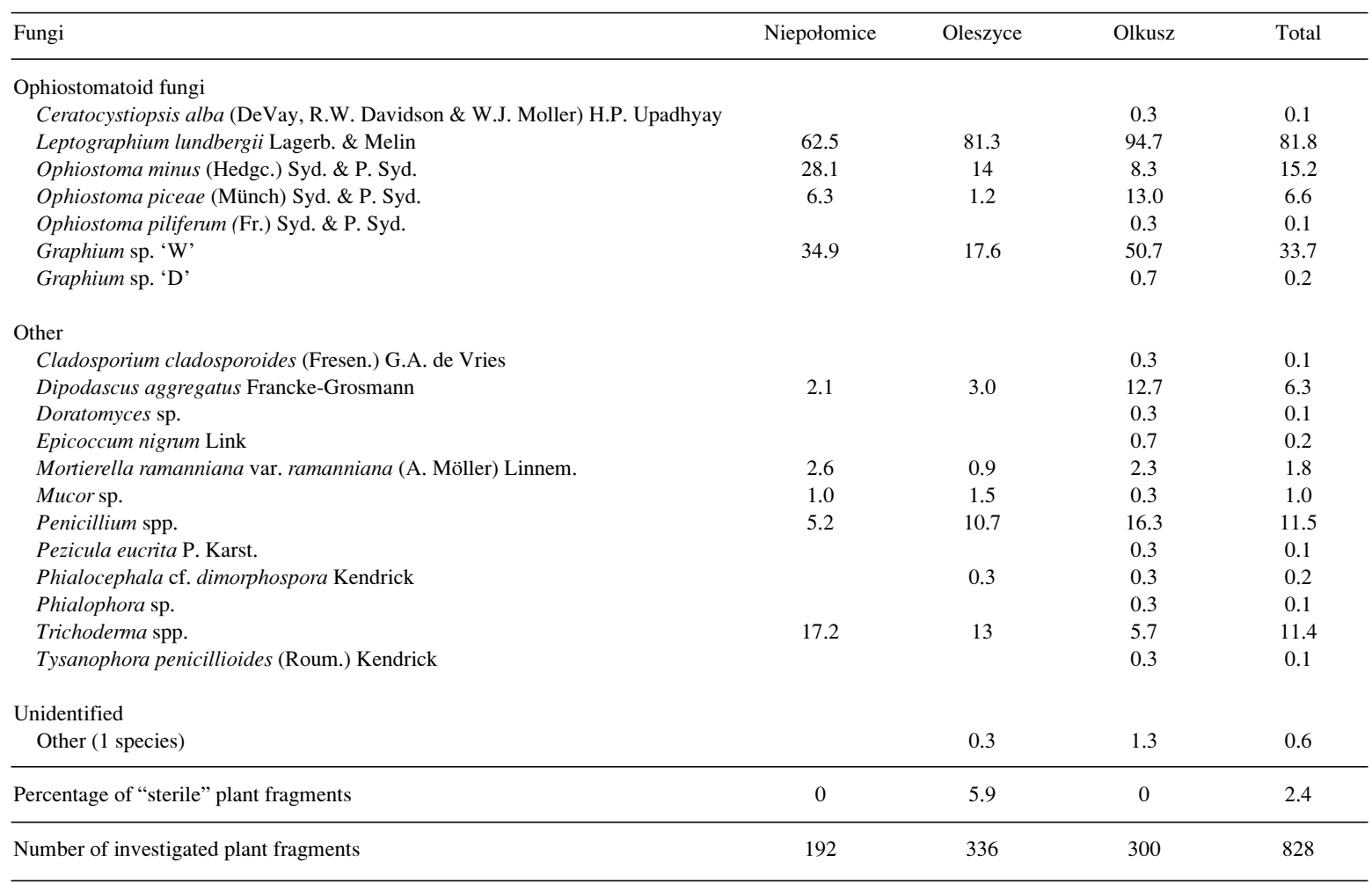

in the sapwood of Scots pine. This study confirms Kotýnková-Sychrová's observation because L. lundbergii was a dominant fungus in the phloem and sapwood samples taken from early galleries of $H$. palliatus. This may indicate that L. lundbergii is able to colonize rapidly the sapwood of Scots pine and is the most important invader of the phloem and sapwood of trees attacked by $H$. palliatus. This fungus was also found in gallery systems of $H$. palliatus with high frequency in Denmark (Harding 1989). Leptographium lundbergii was associated with stained sapwood on pine and spruce, and it was isolated from the gallery systems of many bark beetles (Jacobs and Wingfield 2001; Kirisits 2004). It was first described by Lagerberg and Melin (Lagerberg et. al. 1927). Recently, Jacobs et. al. (2005) have made a taxonomic re-evaluation of this fungus. On the basis of DNA sequence and morphology they gave a new and expanded description of the species. The morphological characteristics of $L$. lundbergii isolates from this study are very similar to the characteristics of the cultures examined by Jacobs et. al. (2005).

The two unidentified species Graphium sp., code-named ' $W$ ' and ' $D$ ' are used here in the broad sense (Seifert and Okada 1993). The taxonomic position of the Graphium sp. 'W' and Graphium sp. 'D' is currently under investigation and will be discussed in a later report. The synnemata of Graphium sp. 'W' had lightly pigmented stipes with cylindrical conidia. This species was also sporadically isolated from Tomicus piniperda L. galleries in Scots pine forests in Poland (Jankowiak 2006). The two unknown Graphium spp. were also isolated from $H$. palliatus by Wingfield and Gibbs (1991) in England but the authors did not give any description of these species.
The results presented here suggest that $H$. palliatus may be effective vector for $O$. minus. It is interesting because this fungus had never been reported in association with $H$. palliatus. So far this species has been described as associated with other bark beetle species on Pinus spp. (Mathiesen 1950; Mathiesen-Käärik 1953; Lieutier et. al. 1989; Rennerfelt 1950; Siemaszko 1939; Solheim and Långström 1991). In Poland this fungus was found in connection with T. piniperda, Ips sexdentatus (Jankowiak 2006, Jankowiak unpublished, Siemaszko 1939) and T. minor (Hrtg.) (Jankowiak, unpublished). Ophiostoma minus associated with $T$. piniperda on $P$. sylvestris is able to kill trees in experimental mass inoculations (Långström et. al. 1993; Solheim et. al. 1993). In contrast to O. minus, L. lundbergii is not highly virulent and may be a secondary pathogen (Harrington and Cobb 1988). In this study, inoculation tests with the ophiostomatoid fungi isolated from $H$. palliatus have not been conducted. Studies on pathogenicity of the fungi against Scots pine are conducted.

Ophiostoma piceae was relatively frequently isolated from galleries of $H$. palliatus. Thus, the relatively high frequency of occurrence of $O$. piceae was not a surprise because this fungus was frequently isolated from beetles and galleries of other bark beetle species attacking Norway spruce in Europe (Harding 1989; Kirschner 1998; Mathiesen-Käärik 1953). This study showed that $O$. piceae is also an important associate of $H$. palliatus in Poland.

Penicillium and Trichoderma species were also commonly isolated from galleries of $H$. palliatus in this study. Adult insects usually spend the winter in the soil and can easily introduce litter and soil fungi such as Trichoderma, Penicillium and Mortierella ramanniana var. ramanniana 
to the pine trunks. This group of fungi is not associated with any specific species of bark beetles on forest trees (Kirschner 2001).

Some of the remaining species isolated from phloem and sapwood represent endophytes associated with $P$. sylvestris. Such species as Epicoccum nigrum Link, Pezicula eucrita $\mathrm{P}$. Karst. or Phialocephala cf. dimorphospora W.B. Kendr. were frequently isolated from symptomless and uncolonized Scots pine trees (Kowalski and Kehr 1996). The other non-ophiostomatoid fungi were rarely associated with $H$. palliatus and represent entomochoric fungi (Dipodascus aggregatus), nematode-destroying fungi (Harposporium sp.), wood colonizing fungi (Phialophora sp.) and other ecological groups (Kirschner 2001).

In conclusion, the results of the study confirmed previously reported associations between many ophiostomatoid fungal species and $H$. palliatus in other parts of Europe. However, the pathogenic $O$. minus and $O$. piliferum have not been previously reported. The majority of ophiostomatoid fungi isolated from $H$. palliatus infesting Norway spruce were not found in this study.

\section{ACKNOWLEDGEMENTS}

This work was supported by the Ministry of Education and Science, Poland, grant no. 2PO6L 008 28. I thank Robert Rossa for identification of the Hylurgops palliatus beetles.

\section{LITERATURE CITED}

HARDING S. 1989. The influence of mutualistic blue stain fungi on bark beetle population dynamics. Ph.D. thesis. Department of Zoology, Royal Veterinary \& Agricultural University. Copenhagen.

HARRINGTON T.C., COBB F. 1988. Leptographium root diseases on Conifers. St Paul, MN, American Phytopathological Society.

HARRINGTON T.C. 1993: Diseases of conifers caused by species of Ophiostoma and Leptographium. In: M.J. Wingfield, K.A. Seifert, J.F. Webber (eds). Ceratocystis and Ophiostoma. Taxonomy, ecology and pathogenicity: 161-172. St Paul, MN, American Phytopathological Society.

JACOBS K., WINGFIELD M.J. 2001. Leptographium species: Tree pathogens, insect associates and agents of bluestain. St Paul, MN, American Phytopathological Society.

JACOBS K., WINGFIELD M.J., COETSEE C., KIRISITS T., WINGFIELD B.D. 2001. Leptographium guttulatum sp. nov., a new species from spruce and pine in Europe. Mycologia 93: 380-388.

JACOBS K., SOLHEIM H., WINGFIELD B.D., WINGFIELD M.J. 2005. Taxonomic re-evaluation of Leptographium lunbergii based on DNA sequence comparisons and morphology. Mycol. Res. 109: 1149-1161.

JANKOWIAK R. 2005. Fungi associated with Ips typographus on Picea abies in Southern Poland and their succession into the phloem and sapwood of beetle-infested trees and logs. Forest Pathology 35: 1-19.

JANKOWIAK R. 2006. Fungi associated with Tomicus piniperda in Poland and assessment of their virulence using Scots pine seedlings. Annals of Forest Science, 63: 801-808.

KIRISITS T., GRUBELNIK R., FÜHRER E. 2000. Die ökologische Bedeutung von Bläuepilzen für rindenbrütende Borkenkäfer. [The ecological role of blue-stain fungi for phloemfeeding bark beetles]. In: F. Müller (eds) Mariabrunner Wald- bautage 1999 - Umbau sekundärer Nadelwälder: 117-137. Vienna: Schriftenreihe der Forstlichen Bundesversuchsanstalt Wien, FBVA-Berichte 111.

KIRISITS T. 2001. Studies on the association of ophiostomatoid fungi with bark beetles in Austria with special emphasis on Ips typographus and Ips cembrae and their associated fungi Ceratocystis polonica and Ceratocystis laricicola. Dissertation, Universität für Bodenkultur Wien.

KIRISITS T. 2004. Fungal associates of European bark beetles with special emphasis on the ophiostomatoid fungi. In: F. Lieutier, K.R. Day, A. Battisti, J.C. Grégoire, H. Evans, H. (eds), Bark and Wood Boring Insects in Living Trees in Europe, A Synthesis: 185-235. Dordrecht: Kluwer.

KIRSCHNER R. 1998. Diversität mit Borkenkäfern assoziierter filamentöser Mikropilze. Dissertation, Eberhard-Karls-Universität Tübingen.

KIRSCHNER R. 2001. Diversity of filamentous fungi in bark beetle galleries in central Europe. In: J.K. Misra, B.W. Horn (eds), Trichomycetes and other fungal groups: 175-196. Robert W. Lichtwardt Commemoration Volume. Enfield, Plymouth: Science Publishers, Inc.

KOWALSKI T., KEHR R.D. 1996. Fungal endophytes of living branch bases in several European tree species. In: S.C. Redlin L.M. Carris (eds), Endophytic fungi in grasses and woody plants; systematics, ecology, and evolution: 67-86. St Paul, MN, American Phytopathological Society.

KOTÝNKOVÁ-SYCHROVÁ E. 1966. Mykoflóra chodeb kůrovců v Èeskoslovensku. Ėeská Mycologie 20: 45-53. (in Czech with English summary)

KROKENE P., SOLHEIM H. 1996. Fungal associates of five bark beetle species colonizing Norway spruce. Can. J. For. Res. 26: 2115-2122.

LAGERBERG T., LUNDBERG G., MELIN E. 1927. Biological and practical researches into blueing in pine and spruce. Svenska Skogsvårdsföreningens Tidskrift 25: 145-272.

LÅNGSTRÖM B., SOLHEIM H., HELLQVIST C., GREF R. 1993. Effects of pruning young Scots pines on host vigour and susceptibility to Leptographium wingfieldii and Ophiostoma minus, two blue-stain fungi associated with Tomicus piniperda. Eur. J. For. Path. 23: 400-415.

LIEUTIER F., YART A., GARCIA J., HAM M.C., MORELET M., LEVIEUX J. 1989. Champignons phytopathogènes associès à deux colèoptères scolytidae du pin sylvestre (Pinus sylvestris L.) et etude prèliminaire de leur agressivitè envers I'hôte. Ann. Sci. For. 46: 201-216.

MATHIESEN A. 1950. Über einige mit Borkenkäfern assoziierten Bläuepilze in Schweden. Oikos 2: 275-308.

MATHIESEN-KÄÄRIK A. 1953. Eine Übersicht über die gewöhnlichsten mit Borkenkäfern assoziierten Bläuepilze in Schweden und einige für Schweden neue Bläuepilze. Meddelanden från Statens Skogforskningsinstitutut 43: 1-74.

MICHALSKI J., MAZUR A. 1999. Korniki. Praktyczny przewodnik dla leśników. Oficyna Edytorska "Wydawnictwo Świat", Warszawa. (in Polish)

RENNERFELT E. 1950. Über den Zusammenhang zwischen dem Verblauen des H olzes und den Insekten. Oikos 2: 120-137.

SALLÈ A., MONCLUS R., YART A., GARCIA J., ROMARY P., LIEUTIER F. 2005. Fungal flora associated with Ips typographus: frequency, virulence, and ability to stimulate the host defence reaction in relation to insect population levels. Can. J. For. Res. 35: 365-373.

SEIFERT K.A., OKADA G. 1993. Graphium anamorphs of Ophiostoma species and similar anamorphs of other ascomycetes. In: M.J. Wingfield, K.A. Seifert, J.F. Webber (eds). Ceratocystis and Ophiostoma. Taxonomy, ecology and pathogenicity: 27-41. St Paul, MN, American Phytopathological Society.

SIEMASZKO W. 1939. Zespoły grzybów towarzyszących kornikom polskim. Planta pol. 7: 1-54. (in Polish with English summary) 
SOLHEIM H. 1986. Species of Ophiostomataceae isolated from Picea abies infested by the bark beetle Ips typographus. Nord. J. Bot. 6: 199-207.

SOLHEIM H., LÅNGSTRÖM B. 1991. Blue-stain fungi associated with Tomicus piniperda in Sweden and preliminary observations on their pathogenicity. Ann. Sci. For. 48: 149-156.

SOLHEIM H., LÅNGSTRÖM B., HELLQVIST C. 1993. Pathogenicity of the blue-stain fungi Leptographium wingfieldii and Ophiostoma minus to Scots pine: effect of tree pruning and inoculum density. Can. J. For. Res. 23: 1438-1443.

UPADHYAY H.P. 1981. A Monograph of Ceratocystis and Ceratocystiopsis. The University of Georgia Press, Athens, Georgia.
VIIRI H. 1997. Fungal associates of the spruce bark beetle Ips typographus L. (Col. Scolytidae) in relation to different trapping methods. J. Appl. Entomol. 121: 529-533.

VIIRI H., LIEUTIER F. 2004. Ophiostomatoid fungi associated with the spruce bark beetle, Ips typographus, in three areas in France. Ann. For. Sci. 61: 215-219.

WINGFIELD M.J., GIBBS J.N. 1991. Leptographium and Graphium species associated with pine- infesting bark beetles in England. Mycol. Res. 95: 1257-1260.

WINGFIELD M.J., SEIFERT K.A., WEBBER J.F. (eds) 1993. Ceratocystis and Ophiostoma. Taxonomy, ecology and pathogenicity. St Paul, MN: American Phytopathological Society. 